\title{
Intact Nuclear Families: Associations between Parental Styles and School Children's Behavior
}

\author{
Aline Sanches Politi Sebastião ${ }^{1}$ \\ Ana Paula Casagrande Silva Rodrigues' \\ Fernanda Aguiar Pizeta ${ }^{2}$ \\ Sonia Regina Loureiro ${ }^{1}$ \\ ${ }^{1}$ Universidade de São Paulo \\ ${ }^{2}$ Universidade Paulista
}

\begin{abstract}
Regardless of family configurations, few studies address the concomitant assessment of mothers and fathers regarding their children's behaviors and parenting practices. The objective was to compare and correlate the assessment of biological mothers and fathers of intact nuclear families on their parental practices and behavioral problems of their school-aged children. Fourth-two intact nuclear families answered to the following instruments: General Questionnaire, Parenting Style Inventory, Strengths and Difficulties Questionnaire and Raven Progressive Matrices Test - Special Scale. The quantitative analysis showed that mothers and fathers presented similar assessments regarding the behavior of their children, though mothers reported more positive practices than fathers. Negative parenting styles were positively correlated with child behavioral problems. These findings contribute to the planning of preventive strategies and interventions directed to families.

Keywords: family relations; child rearing; child behavior
\end{abstract}

\section{Famílias Nucleares Intactas: Associações entre Estilos Parentais e Comportamento de Escolares}

\section{Resumo}

Independente da configuração familiar, poucos estudos têm abordado as avaliações concomitantes de mães e pais sobre os comportamentos e práticas educativas adotadas com seus filhos. Objetivou-se comparar e correlacionar a avaliação de mães e pais biológicos, de famílias nucleares intactas, sobre suas práticas educativas e problemas comportamentais de seus filhos, em idade escolar. Foram avaliadas 42 famílias nucleares intactas, que responderam aos seguintes instrumentos: Questionário Geral, Inventário de Estilos Parentais, Questionário de Capacidades e Dificuldades da Criança e Teste das Matrizes Progressivas de Raven - Escala Especial. Por meio de análise quantitativa, verificou-se que mães e pais apresentaram semelhanças quanto às avaliações sobre o comportamento dos filhos e que mães referiram mais práticas positivas do que pais. As práticas parentais negativas correlacionaram-se positivamente com os problemas de comportamento. Tais achados contribuem para o planejamento de estratégias de prevenção e intervenção com famílias.

Palavras-chave: relações familiares, educação infantil, comportamento infantil

\section{Familias Nucleares Intactas: Asociaciones Entre Estilos Parentales y Comportamiento de Escolares}

\begin{abstract}
Resumen
Independiente de la configuración familiar, pocos estudios han abordado las evaluaciones concomitantes de madres y padres sobre los comportamientos y prácticas educativas adoptadas con sus hijos. Se tuvo como objetivo comparar y correlacionar la evaluación de madres y padres biológicos, de familias nucleares intactas, sobre las prácticas educativas y problemas comportamentales de sus hijos en edad escolar. Fueron evaluadas 42 familias nucleares intactas, que respondieron a los siguientes instrumentos: Cuestionario General, Inventario de Estilos Parentales, Cuestionario de Capacidades y Dificultades del Niño y Test de las Matrices Progresivas de Raven - Escala Especial. Por medio de un análisis cuantitativo, se verificó que madres y padres presentaron semejanzas con relación a las evaluaciones sobre el comportamiento de los hijos y que las madres mencionaron más prácticas positivas que los padres. Las prácticas parentales negativas se correlacionan positivamente con los problemas de comportamiento. Estos resultados contribuyen para la planificación de estrategias de prevención e intervención con las familias. Palabras clave: relaciones familiares, educación infantil, comportamiento infantil
\end{abstract}

\section{Introduction}

Various studies have addressed changes that have taken place over time in family configurations, including nuclear families with different arrangements (Cunico \& Arpini, 2014; Gomes, Crepaldi, \& Bigras, 2013; Leme, Del Prette, \& Coimbra, 2013). A nuclear family is considered a protective factor for child development and
Cerveira (2015) identified it as being more functional, cohesive, flexible, and having better communication than single-parent families. Crestani, Mattana, Moraes and Souza (2013) note there are fewer risks to development when children live with both parents.

Mothers are widely seen as the main caregivers and an important support to the development of children. The review conducted by Vieira et al., (2014), however, 
which analyzed studies published from 2000 to 2012, shows that fathers are gaining increasing attention in studies addressing families, while the empirical study conducted by Cia and Barham (2009) reports that the better the communication established between fathers and children and the greater the participation of fathers in raising children, the fewer behavior problems children experience.

Intact nuclear families, characterized by the presence of a father and a mother, is a condition that can provide children with a conducive family environment, as both can share the care provided to children and related responsibilities, as well as house chores (Manfroi, Macarini, \& Vieira, 2011). By sharing the care provided to children, mothers and fathers can be more available and present to establish positive interactions with their children (Arrais, 2012).

The relationships established between parents and children are the basis for healthy child development and are essential for the socialization of children, beginning at birth. Especially during the period of attending school, the pattern of rules and affective climate established in the interaction between parents and children play an important role in the children's emotional balance (Gomide, 2007; Mondin, 2006), favoring the development of competencies in the relationship children establish with their peers and those outside the family. Many studies have addressed the relationship between parents and children by considering potential associations between the quality of this relationship and rearing practices with behavioral problems and academic performance (Leme \& Marturano, 2014; Marin, Piccinini, \& Tudge, 2011), as well as how these influence the development of socially appropriate and inappropriate behaviors (Salvador \& Weber, 2005).

However, there is no consensus regarding the denomination of the different forms with which parents relate to children (Alvarenga \& Piccinini, 2001; Macarini, Martins, Minetto, \& Vieira, 2010), so that choosing a theory is a necessary condition to making comparisons with other studies in the future. In this study we adopted the concepts proposed by Gomide (2006), who called Parenting Styles the set of rearing practices mothers and fathers adopt to raise, socialize, and control the behavior or their children. Gomide notes parenting styles are expressed through seven models, namely: positive monitoring and moral behavior, which refer to positive parenting practices; and physical abuse, negative monitoring, neglect, and inconsistent punishment, which refer to negative practices.
Among positive practices, positive monitoring includes actions that involve the attention of parents regarding what their children are doing, where and with whom they are. Moral behavior, in turn, refers to a set of actions intended to convey values and virtues. Such positive practices, when used as disciplinary strategies, may favor the development of prosocial behaviors in children (Gomide, 2006; Mondin, 2006).

Negative practices, however, are parental models that may favor the development of aggressive and antisocial behaviors and a refusal to comply with rules (Gomide, 2006; Mondin, 2006). Among such practices, physical abuse is defined as actions that physically hurt children; relaxed discipline consists in not correcting children when they circumvent imposed rules and limits; excessive control and surveillance characterize negative monitoring; neglect is characterized by a lack of responsibility on the part of parents toward their children; and finally, inconsistent punishment occurs when parents punish or reinforce children based on their own mood states (Gomide, 2006).

Patias, Siqueira and Dias (2012) verified in a literature review that negative practices might harm children's development, while positive practices have a positive impact on their development. The adoption of fewer positive practices and more frequently adopting negative practices may lead to the development of both externalizing and internalizing behavioral problems (Nunes, Vieira, \& Rubin, 2013; Salvo, Silvares, \& Toni, 2005). Externalizing problems refer to noticeable behavioral patterns, characterized by aggressiveness, hyperactivity, restlessness, disobedience, delinquency and impulsive behavior. Internalizing problems are behavioral patterns in terms of emotional problems characterized by shyness, anxiety, depression, sadness, fear and exaggerated worries (Achenbach, 2008; Borsa \& Nunes, 2008; Wielewicki, 2011).

Various studies addressing the positive influences of interactions established between parents and children and behavioral outcomes among children report there is a positive association between negative parenting practices and behavioral problems (Bolsoni-Silva, Loureiro, \& Marturano, 2016; Cardoso, 2015; Pinheiro, 2015; Sakuramoto, Squassoni, \& Matsukura, 2014) or psychopathology among children (Bornovalova, Blazei, Malone, McGue, \& Iacono, 2013). Positive parenting practices, in turn, are protective factors that promote the wellbeing of children, favoring resilience in the face of adversities (Macana \& Comim, 2015; Patias et al., 2013) and are negatively correlated with behavioral 
problems during childhood (Marin, Piccinini, Gonçalves, \& Tudge, 2012).

When addressing parenting practices, regardless of the family composition, one should take into account the perceptions of both parents responsible for raising children (Faria, 2015; Venâncio, 2015). Various factors can lead to differences between parents in terms of child-rearing practices, namely: quality and quantity of time of interaction between mother, father and children; quality of the marital relationship; and specific characteristics of the mother and father, in addition to social and cultural conditions that define parenting roles (Borsa \& Nunes, 2008). Few studies, however, include the assessments of both parents, showing there is a lack of information regarding comparisons between mothers and fathers when they independently assess the behavior of their children (Backes, 2015; Santos, 2015).

This study is intended to fill in this gap and its objective was to compare and correlate assessments of the biological mothers and fathers in intact nuclear families regarding their parenting practices and the behavior of their school-aged children. The following hypotheses were established: mothers and fathers differ in how they assess the behavior of their children and also in regard to the use of positive and negative parenting practices. Additionally, according to the assessments of both mothers and fathers, children who more frequently present behavioral problems are more frequently exposed to negative parenting practices and less frequently exposed to positive parenting practices.

\section{Method}

This study employs a cross-sectional and correlational design comparing between groups. It was submitted to and approved by the Institutional Review Board and is in compliance with ethical guidelines (CEP - CAAE no 36252314.1.0000.5407).

\section{Participants}

The mothers, fathers and children of 42 intact nuclear families living in a small-sized city in the interior of São Paulo, Brazil participated in this study. The following inclusion criteria were used: biological mother and biological father; married or in a stable relationship (having never been separated since the birth of the child included in the study); with a school-aged child with at least an average cognitive level (percentile equal to or greater than 25 according to Raven's), attending a primary school grade compatible with his/her chronological age. Only one child was included per family. The mothers were 36.14 years old on average $(S D=5.56)$; the fathers were 38.36 years old, on average $(S D=5.03)$; the children were 9.1 years old, on average $(S D=0.85)$. Twenty-three children were girls and 19 were boys, most $(40.50 \%)$ were attending the $5^{\text {th }}$ grade.

\section{Instruments}

General Questionnaire: was developed to collect sociodemographic information and specific data regarding the participants and their families. The Brazilian Criteria of Economic Classification developed by the Brazilian Association of Research Companies (2015) was used to assess socioeconomic conditions.

Inventário de Estilos Parentais [Parenting Styles Inventory (PSI)]: proposed by Gomide (2006), the PSI enables the identification of parenting styles and practices. The inventory contains 42 questions corresponding to seven rearing practices: a) positive practices: positive monitoring and moral behavior; and b) negative: inconsistent punishment, neglect, relaxed discipline, negative monitoring, and physical abuse. There is a subtotal score for each of the seven practices and a total score for positive practices and a total score for negative practices; the difference between the total score of positive practices and the total score of negative results in a Parenting Style Index $(p s i)$. As an inventory, PSI ranges from -60 (lack of positive practices and full presence of negative practices) to +24 (lack of negative practices and full presence of positive practices). In regard to psychometric qualities, the instrument presented high factor loads and good indicators concerning criteria validation (Pasquali, 2003). The instrument's parent version was used in this study to identify parenting practices of both mothers and fathers. The analysis of reliability presented a Cronbach's alpha equal to 0.65 .

Strength and Difficulties Questionnaire (SDQ): developed by Goodman (1997) and validated for the Brazilian context by Fleitlich, Cortázar and Goodman (2000). This instrument is available free of charge (website: www.sdqinfo.com) and its purpose is screening behavioral problems among children and adolescents who are between four and 16 years old. The SDQ presents 25 items, subdivided into five scales: four scales refer to difficulties (emotional symptoms, conduct problems, hyperactivity, and peer relationship problems) and a prosocial behavior scale. The raw scores for each of the scales range from zero to 10 and the total score of difficulties results from the sum of the scores obtained on 
the four scales of behavioral difficulties, ranging from zero to 40. The cut-off point (total score higher than 16) proposed by Goodman (1997) for the total score of difficulties was used to classify children with or without behavioral difficulties. This questionnaire has three versions (parents, professors and adolescents), but only the parent version was used in this study. Psychometric data indicate this instrument has good reliability (Worner et al., 2004) and validity indicators (Fleitlich et al., 2000). The Cronbach's alpha obtained for this sample was equal to 0.80 .

Raven's Progressive Matrices - Special Scale: was adapted by Angeline, Alves, Custódio, Duarte and Duarte (1999) to assess the intellectual level of Brazilian children aged five to 11-and-half years old. Its psychometric qualities are expressed by construct, and precision validity and internal consistency (Angeline et al., 1999). In a recent Brazilian study, Muniz, Gomes and Pasian (2016) addressed the factorial structure of Raven's and verified that this test can be interpreted as a $\mathrm{g}$ factor measure, including specific factors that assess the children's stages of cognitive development. The criterion they used to recruit children for the study was having an intellectual performance equal to or greater than 25 .

\section{Procedures}

\section{Data collection}

The families were identified through their children who were attending three municipal schools and two private schools. After authorization was provided by the schools and the Municipal Education Department, an invitation directed to the parents was distributed to the children, in which families were asked to participate in the study. After providing their consent, the families were contacted by phone, when a date and time was scheduled to provide clarification about the study and collect data.

A total of 732 invitations were distributed, 380 of which were returned. Of those returned, 338 were excluded: 159 families refused to participate; 171 families and/or children did not meet the inclusion criteria; and eight families were excluded due to a lack of compatibility between the father's and mother's availability for the meeting. Thus, a total of 42 intact nuclear families were included in the study.

Data collection was initiated by asking fathers and mothers to sign free and informed consent forms. The families were interviewed at their homes in individual sessions, so that parents could independently answer the instruments, with no communication between parents. A single meeting, lasting two and a half hours on average and divided into three portions, was held with each family. In the first portion of the meeting, the PSI and SDQ were applied to the fathers. In the sequence, the mothers answered the PSI, SDQ and the General Questionnaire and, finally, in the last portion of the meeting, the Raven's Progressive Matrices -Special Scale was applied to the children. We sought to ensure the participants' privacy and comfort and explicitly asked the other family members to avoid interference and external interruptions while the participants were completing the instruments.

\section{Statistical Analysis of Data}

Data obtained using Raven's, SDQ and PSI were coded according to each instrument's technical standards. Data obtained from the General Questionnaire were quantified in order to obtain the sociodemographic profile of the participants and their families. Statistical tests were chosen after verifying the normality of distribution of variables (Shapiro-Wilk test), which were performed using IBM SPSS Statistics (v. 23; IBM SPSS, Chicago, IL), with a level of significance at $5 \%(\mathrm{p} \leq 0.05)$.

The perceptions of parents regarding parenting practices (PSI) and their children's behavioral indicators (SDQ) were compared and treated as continuous variables, in terms of mean and standard deviation, and as categorical variables, for which frequency and percentage were found, determining the presence or absence of behavioral problems according to the SDQ. Matched samples were compared. The Wilcoxon test or Student's test were used for the continuous variables and the McNemar test was used for the dichotomous variables. Separately, the score concerning parenting practices were also compared using the Mann-Whitney test to see whether mothers and fathers identified the presence or absence of behavioral problems.

Spearman's Correlation was used to verify the parents' assessments according to the SDQ and PSI, considering that most variables did not present a parametric distribution or were dichotomous variables. Correlations were classified according to the following: $<0.25$ - weak; between 0.25 and 0.50 - moderate; between 0.50 and 0.75 - strong; and greater than 0.75 - very strong (Marôco, 2014). Cohen d was calculated to estimate effect size and interpreted based on cutoff points described by Cohen (1988): $d=0.2-$ small 
effect; $d=0.5$ - intermediate effect; and $d=0.8$ - large effect (Conboy, 2003). The effect size of the correlations with statistical significance was also calculated and $\mathrm{r}^{2}$ was classified as low $(\leq 0.10)$; moderate $(0.10$ to 0.25$)$; high (0.25 to 0.50$)$; and very high $(>0.50)$, according to Marôco (2014).

\section{Results}

Sociodemographic data reveal that $64.3 \%$ of the mothers had more than eight years of schooling and $69 \%$ had a paid job; $45.2 \%$ of the fathers also had more than eight years of schooling and $97.6 \%$ had a paid job. Most families had up to three children (83.3\%), monthly income up to three times the minimum wage $(59.5 \%)$, and belonged to the economic classes $\mathrm{C}$ or $\mathrm{D}(54.8 \%)$.

Comparison between the assessments performed by the mothers and fathers using the SDQ did not reveal significant statistical differences (Table 1 ), though mothers obtained higher scores, when compared to fathers, concerning total Difficulties and Emotional Symptoms, Hyperactivity, Peer Relationship Problems, and Prosocial Behavior.

No significant differences were found between the assessments of mothers and fathers in regard to the presence or absence of behavioral problems among their children (Table 2). Even though no statistical significance was found, mothers more frequently than fathers reported the presence of emotional difficulties among the children.

Comparison between the assessments of mothers and fathers in regard to specific parenting practices (total Positive Practices, total Negative Practices, and psi) shows significant statistical differences in regard to total Positive Practices and to the Positive Monitoring scale; the mothers obtained higher means (Table 3). The means obtained by the mothers in the Moral Behavior, Inconsistent Punishment, Negative Monitoring, and Physical Abuse scales, total Negative Practices, and $p s i$ were also higher than those obtained by the fathers, though with no statistically significant difference.

When the assessments of mothers and fathers, in regard to parenting practices, were compared to the parents' assessment as to whether their children presented behavioral problems, mothers rated themselves with higher scores for Negative Practices, Neglect, Relaxed Discipline, and Physical Abuse, while fathers rated themselves as having higher scores for Negative Practices and Relaxed Discipline. Children assessed as not having behavioral problems, a difference that was statistically significant, had mothers who rated themselves as more frequently using positive practices and less frequently using negative practices $\left(p_{s i}\right)$. Only significant correlations, between parenting practices and

Table 1.

Comparisons: perceptions of Mothers and Fathers regarding Children's Behaviors (SDQ) $(n=42)$

\begin{tabular}{|c|c|c|c|c|}
\hline \multirow{2}{*}{$\begin{array}{l}\text { Respondents } \\
\text { SDQ }\end{array}$} & $\begin{array}{l}\text { Mothers } \\
(\mathrm{n}=42)\end{array}$ & Fathers $(n=42)$ & \multirow{2}{*}{ Test value } & \multirow{2}{*}{$\mathrm{p}$-value } \\
\hline & $\begin{array}{c}\text { Mean } \\
(\mathrm{SD})\end{array}$ & $\begin{array}{c}\text { Mean } \\
(\mathrm{SD})\end{array}$ & & \\
\hline Emotional Symptoms & $\begin{array}{c}4.43 \\
(2.63)\end{array}$ & $\begin{array}{c}3.64 \\
(2.44)\end{array}$ & -1.882 & 0.060 \\
\hline Conduct Problems & $\begin{array}{l}2.05 \\
(2.01)\end{array}$ & $\begin{array}{c}2.10 \\
(1.96)\end{array}$ & -0.152 & 0.879 \\
\hline Hyperactivity & $\begin{array}{c}4.00 \\
(2.65)\end{array}$ & $\begin{array}{c}3.60 \\
(2.52)\end{array}$ & -0.913 & 0.361 \\
\hline Peer Relationship Problems & $\begin{array}{c}1.81 \\
(1.76)\end{array}$ & $\begin{array}{c}2.14 \\
(1.70)\end{array}$ & -1.013 & 0.311 \\
\hline Total Difficulties & $\begin{array}{l}12.29 \\
(7.11)\end{array}$ & $\begin{array}{l}11.48 \\
(6.32)\end{array}$ & 0.759 & 0.448 \\
\hline ProSocial Behavior & $\begin{array}{c}8.98 \\
(1.42)\end{array}$ & $\begin{array}{c}8.40 \\
(1.81)\end{array}$ & -1.746 & 0.081 \\
\hline
\end{tabular}

Note. $\mathrm{p}$-value refers to the Wilcoxon test $\mathrm{p} \leq 0.05 ; \mathrm{SD}=$ Standard Deviation

Psico-USF, Bragança Paulista, v. 25, n. 1, p. 115-126, jan./ mar. 2020 
Table 2

Comparison between Mothers and Fathers concerning the Presence or Absence of Difficulties among Children (SDQ) $(n=42)$

\begin{tabular}{|c|c|c|c|c|}
\hline \multirow[t]{2}{*}{ SDQ } & Respondents & $\begin{array}{c}\text { Mothers } \\
(\mathrm{n}=42)\end{array}$ & $\begin{array}{l}\text { Fathers } \\
(n=42)\end{array}$ & \multirow[t]{2}{*}{ p-value* } \\
\hline & & $\mathrm{f}(\%)$ & $\mathrm{f}(\%)$ & \\
\hline \multicolumn{5}{|l|}{ Emotional Symptoms } \\
\hline Without difficulty & & $20(47.6)$ & $26(61.9)$ & 0.109 \\
\hline With difficulty & & $22(52.4)$ & $16(38.1)$ & \\
\hline \multicolumn{5}{|l|}{ Conduct Problems } \\
\hline Without difficulty & & $34(81.0)$ & $32(76.2)$ & 0.688 \\
\hline With difficulty & & $08(19.0)$ & $10(23.8)$ & \\
\hline \multicolumn{5}{|l|}{ Hyperactivity } \\
\hline Without difficulty & & $34(81.0)$ & $36(85.7)$ & 0.727 \\
\hline With difficulty & & 08(19.0) & $06(14.3)$ & \\
\hline \multicolumn{5}{|l|}{ Peer Relationship } \\
\hline Without difficulty & & $33(78.6)$ & $35(83.3)$ & 0.774 \\
\hline With difficulty & & $09(21.4)$ & $07(16.7)$ & \\
\hline \multicolumn{5}{|l|}{ Total Difficulties } \\
\hline Without difficulty & & $33(78.6)$ & $33(78.6)$ & 1.000 \\
\hline With difficulty & & $09(21.4)$ & $09(21.4)$ & \\
\hline \multicolumn{5}{|l|}{ ProSocial } \\
\hline Without difficulty & & 41(97.6) & $40(95.2)$ & 1.000 \\
\hline With difficulty & & $01(02.4)$ & $02(04.8)$ & \\
\hline
\end{tabular}

Note. $\mathrm{f}=$ Frequency $; \%=$ Percentage $; *$ p-value concerning McNemar's test $\mathrm{p} \leq 0.05$.

the children's behavioral problems, classified as moderate, strong or very strong, are described.

According to the mothers' assessments, positive and moderate correlations were found between Conduct Problems and total Negative Practices $(\varrho=0.333$; $\left.\mathrm{r}^{2}=0.11 ; \mathrm{p} \leq 0.05\right)$ and between Peer Relationship Problems and Neglect $\left(\varrho=0.404 ; \mathrm{r}^{2}=0.16 ; \mathrm{p} \leq 0.01\right)$, Negative Monitoring $\left(\varrho=0.420 ; \mathrm{r}^{2}=0.17 ; \mathrm{p} \leq 0.01\right)$, Physical Abuse $\left(\varrho=0.346 ; \mathrm{r}^{2}=0.12 ; \mathrm{p} \leq 0.05\right)$ and $p s i\left(\varrho=0.431 ; \mathrm{r}^{2}=0.18\right.$; $\mathrm{p} \leq 0.01)$. There was also a correlation between total Behavioral Difficulties and $p s i\left(\varrho=0.431 ; \mathrm{r}^{2}=0.18\right.$; $\mathrm{p} \leq 0.01)$, with an emphasis on Physical Abuse $(\varrho=0.380$; $\left.\mathrm{r}^{2}=0.14 ; \mathrm{p} \leq 0.05\right)$.

Positive and moderate correlations were also found, based on the fathers' assessments between Emotional Symptoms and $p$ si $\left(\varrho=0.347 ; \mathrm{r}^{2}=0.12 ; \mathrm{p} \leq 0.05\right)$ and between Conduct Problems and Physical Abuse $\left(\varrho=0.312 ; r^{2}=0.10 ; \mathrm{p} \leq 0.05\right)$. Emotional Symptoms were correlated with Neglect in both the assessments of mothers $\left(\varrho=0.586 ; \mathrm{r}^{2}=0.34 ; \mathrm{p} \leq 0.01\right)$ and fathers $\left(\varrho=0.357 ; \mathrm{r}^{2}=0.12 ; \mathrm{p} \leq 0.05\right) ;$ as well as with Physical Abuse (mothers: $\varrho=0.446 ; \mathrm{r}^{2}=0.20 ; \mathrm{p} \leq 0.01$; fathers: $\left.\varrho=0.407 ; \mathrm{r}^{2}=0.16 ; \mathrm{p} \leq 0.01\right)$ and with total Negative Practices (mothers: $\varrho=0.367 ; \mathrm{r}^{2}=0.13 ; \mathrm{p} \leq 0.05$; fathers: $\left.\varrho=0.379 ; \mathrm{r}^{2}=0.14 ; \mathrm{p} \leq 0.05\right)$. Conduct Problems were correlated with Relaxed Discipline (mothers: $\varrho=0.584$; $\mathrm{r}^{2}=0.34 ; \mathrm{p} \leq 0.05$; fathers: $\left.\varrho=0.307 ; \mathrm{r}^{2}=0.09 ; \mathrm{p} \leq 0.05\right)$ and with Moral Behavior (mothers: $\varrho=0.367 ; \mathrm{r}^{2}=0.13$; $\mathrm{p} \leq 0.05$; fathers: $\left.\varrho=0.364 ; \mathrm{r}^{2}=0.13 ; \mathrm{p} \leq 0.05\right)$.

\section{Discussion}

This study compared and correlated the assessments of mothers and fathers of intact nuclear families in regard to their parenting practices and the behavior of their school-aged children. The assessments of mothers and fathers concerning parenting practices (positive and negative), as well as their perceptions 
Table 3.

Comparisons between the Assessments of Mothers and Fathers: Parenting Practices (PSI) $(n=42)$

\begin{tabular}{|c|c|c|c|c|}
\hline \multirow{2}{*}{$\begin{array}{c}\text { Respondents } \\
\text { PSI }\end{array}$} & $\begin{array}{l}\text { Mothers } \\
(\mathrm{n}=42)\end{array}$ & $\begin{array}{l}\text { Fathers } \\
(\mathrm{n}=42)\end{array}$ & \multirow{2}{*}{ Test value } & \multirow{2}{*}{ p-value } \\
\hline & $\begin{array}{c}\text { Mean } \\
(\mathrm{SD})\end{array}$ & $\begin{array}{c}\text { Mean } \\
(\mathrm{SD})\end{array}$ & & \\
\hline$\Sigma$ Positive Practices & $\begin{array}{l}21.60 \\
(2.33)\end{array}$ & $\begin{array}{l}20.31 \\
(3.34)\end{array}$ & -2.295 & $0.022^{2}$ \\
\hline Positive Monitoring & $\begin{array}{l}11.24 \\
(1.28)\end{array}$ & $\begin{array}{l}10.10 \\
(1.87)\end{array}$ & -3.291 & $0.001^{2}$ \\
\hline Moral Behavior & $\begin{array}{l}10.36 \\
(1.51)\end{array}$ & $\begin{array}{l}10.21 \\
(1.80)\end{array}$ & -0.549 & $0.583^{2}$ \\
\hline$\Sigma$ Negative Practices & $\begin{array}{l}19.05 \\
(6.78)\end{array}$ & $\begin{array}{l}18.17 \\
(6.86)\end{array}$ & 0.590 & $0.558^{1}$ \\
\hline Inconsistent Punishment & $\begin{array}{l}03.00 \\
(2.01)\end{array}$ & $\begin{array}{l}02.62 \\
(1.91)\end{array}$ & -0.992 & $0.321^{2}$ \\
\hline Neglect & $\begin{array}{l}02.48 \\
(1.95)\end{array}$ & $\begin{array}{l}02.93 \\
(1.85)\end{array}$ & 0.960 & $0.337^{2}$ \\
\hline Relaxed Discipline & $\begin{array}{l}03.33 \\
(2.89)\end{array}$ & $\begin{array}{l}03.64 \\
(2.06)\end{array}$ & 0.617 & $0.537^{2}$ \\
\hline Negative Monitoring & $\begin{array}{l}08.02 \\
(1.87)\end{array}$ & $\begin{array}{l}07.26 \\
(2.22)\end{array}$ & 1.89 & $0.065^{1}$ \\
\hline Physical Punishment & $\begin{array}{l}02.21 \\
(1.73)\end{array}$ & $\begin{array}{l}01.67 \\
(1.68)\end{array}$ & -1.825 & $0.068^{2}$ \\
\hline Psi & $\begin{array}{l}02.55 \\
(7.80) \\
\end{array}$ & $\begin{array}{l}02.24 \\
(8.67) \\
\end{array}$ & 0.179 & $0.859^{1}$ \\
\hline
\end{tabular}

Note. PSI $=$ Parenting Styles Inventory; ${ }^{1} \mathrm{p}$-value concerning Student's t test $\mathrm{p} \leq 0.05 ;{ }^{2} \mathrm{p}$-value concerning the Wilcoxon test $\mathrm{p} \leq 0.05 ; \mathrm{SD}=$ Standard Deviation; $p s i=$ parenting style index ( $\Sigma$ Positive practice $-\Sigma$ Negative Practices).

regarding the behavior of their children, were expected to differ, while children experiencing more behavioral problems were expected to be exposed more frequently to negative parenting practices and less frequently exposed to positive parenting practices, also according to the perceptions of mothers and fathers.

This study is based on a known protective condition for child development, namely intact nuclear families, (Cerveira, 2015), a family configuration that favors the division of home chores and care provided to children (Manfroi et al., 2011; Mondin, 2006). Additionally, both parents become responsible for raising and supporting their children (Arrais, 2012; Crestani et al., 2013; Leme \& Marturano, 2014).

The perceptions of both mothers and fathers, measured by the same instruments, regarding their children's behavioral problems and difficulties, were homogeneous. This finding contrasts with the findings reported by Borsa and Nunes (2008), who suggest that the perceptions of mothers and fathers differ due to the quality and quantity of time they spend with their children.

In regard to parenting practices, the mothers more frequently report positive practices and positive monitoring, compared to fathers, suggesting they represent a protective factor in the development of children. This idea is based on the reports of Macana and Comim (2015), who believe that parents contribute to the wellbeing of children when they establish good quality interactions with them and show interest in their lives, monitor and spend time with their children, and provide emotional support enabling them to have positive socioemotional and cognitive development. The difference between the assessments of mothers and fathers, 
however, was not statistically significant, possibly because the regular presence of fathers in the routines of their families may have resulted in both mothers and fathers providing similar perceptions regarding the behavior of their children.

Another aspect to be analyzed is the fact that children with difficulties are less frequently exposed to positive practices and more frequently exposed to negative practices, such as neglect, relaxed discipline, and physical abuse. This finding is in agreement with that of Mondin (2006), who addressed preschoolers and reports that when parents adopt punitive practices (physical abuse) as a disciplinary tool to control the behavior of children, they tend to favor aggressiveness and non-compliance with rules. Thus, a greater understanding was obtained regarding the association of negative parenting practices and behavioral problems among school-aged children.

In regard to correlations, we verified that in both the assessments of mothers and fathers, emotional symptoms (internalizing behavior manifestations) were correlated with neglect, physical abuse, and other negative practices. This finding agrees with the study by Bolsoni-Silva et al., (2016), who verified the presence of internalizing problems with a greater frequency of negative practices. Similarly, the review conducted by Patias et al., (2012) reports that physical punishment may result in psychological problems during child development because it is a practice that causes fear and insecurity, which contributes to lowering children's self-esteem.

On the other hand, conduct problems (externalizing behavioral problems) were associated with relaxed discipline and less frequent moral behavior, reflecting a difficulty children experience learning social rules and norms, whether because their parents do not enforce rules or because they do not model behaviors that teach children rules and norms (Gomide, 2006; Patias et al., 2013). Similar results were found in the study by Nunes et al., (2013), who verified that when mothers and fathers did not control their children's behavior, these tended to become more aggressive. Other studies also report association between the use of negative parenting practices and children's behavioral problems (Marin et al., 2012; Pinheiro, 2015) and between less frequent positive parenting practices and children's behavioral problems (Salvo et al., 2005).

According to Mondin (2006), association between negative parenting practices and internalizing and externalizing manifestations may be associated with the parents' difficulty showing affection, complying with rules and spending time with children. In this study, negative parenting practices, expressed by low psi, were predominant among both the fathers and mothers of children with behavioral problems; that is, scores concerning negative parenting practices were higher than scores concerning positive practices. These results reveal children are exposed to adverse developmental conditions, showing the importance of preventive programs and interventions focused on parenting practices directed to mothers and fathers, in order to promote positive practices and minimize negative ones, as a resource to ensure the mental health of school-aged children.

\section{Final Considerations}

Among the hypotheses proposed in this study, two were confirmed, that is: mothers and fathers differ in regard to the use of positive and negative parenting practices and that children with behavioral problems were more frequently exposed to negative parenting practices than to positive practices.

This study presents some limitations: (a) the crosssectional design does not allow the temporal sequence of the parenting practices adopted by mothers and fathers and the behaviors of children to be verified; and (b) the small number of families taking part in this study limited analysis concerning the sex of children and other sociodemographic conditions. We suggest that future studies adopt a longitudinal design to analyze these variables at different points over the course of children's development, possibly identifying critical times and examining potential differences between the parenting practices adopted by mothers and fathers toward boys and girls and also that samples with different family configurations be included in the same study.

This study's objectives were achieved and its results contributed to a better understanding of behavioral indicators of school-aged children and parenting practices adopted by mothers and fathers of intact families, favoring the planning of preventive strategies and interventions directed to parents and children.

\section{References}

Achenbach, T. M., Becker, A., Dopfner, M., Heiervang, E., Roessner, V., Steinhausen, H. C., \& Rothenberger, A. (2008). Multicultural assessment of child and adolescente psychopathology with ASEBA and SDQ instruments: research findings, 
applications, and future directions. Journal of Child Psycholigy and Psuchiatry, 49(3), 251-275. doi: 10.1111/j.1469-7610.2007.01867.x

Alvarenga, P., \& Piccinini, C. (2001). Práticas educativas maternas e problemas de comportamento em pré-escolares. Psicologia: Reflexão e Crítica, 14(3), 449460. doi: 10.1590/S0102-79722001000300002

Angelini, A. L., Alves, I. C., Custódio, E. M., Duarte, W. F., \& Duarte, J. L. (1999). Manual das matrizes progressivas coloridas de Raven: Escala especial. São Paulo: Centro Editor de Testes e Pesquisas em Psicologia.

Arrais, A. I. L. (2012). Envolvimento paterno, stress parental e apoio social em pais de crianças em idade escolar (Dissertação de Mestrado, Universidade de Lisboa). Recuperado de http://hdl.handle.net/10451/6911

Associação Brasileira de Empresas de Pesquisa - ABEP (2015). Critério de classificação econômica Brasil. Recuperado de www.abep.org

Backes, M. S. (2015). A relação entre envolvimento paterno e a abertura ao mundo empais de crianças entre quatro a seis anos (Dissertação de Mestrado, Universidade Federal de Santa Catarina). Recuperado de https://repositorio.ufsc.br/xmlui/handle/123456789/133087

Bolsoni-Silva, A. T., Loureiro, S. R., \& Marturano, E. M. (2016). Comportamentos internalizantes: associações com habilidades sociais, práticas educativas, recursos do ambiente familiar e a depressão materna. Psico Porto Alegre, 47(2), 111-120. doi: 10.15448/1980-8623.2016.2.20806

Bornovalova, M. A., Blazei, R., Malone, S., McGue, M., \& Iacono, W.G. (2013). Disentangling the relative contribution of parental antisociality and family discord to child disruptive disorders. Personality $\mathrm{Di}$ sorders, 4(3), 239-246. doi: 10.1037/a0028607

Borsa, J. C., \& Nunes, M. L. T. (2008). Concordância parental sobre problemas de comportamento infantil através do CBCL. Paidéia, 18(40), 317-330. doi: 10.1590/S0103-863X2008000200009

Cardoso, C. M. D. (2015). Os estilos educativos parentais e a hiperatividade em crianças do $1^{\circ}$ ciclo do ensino básico (Dissertação de Mestrado, Instituto Superior Miguel Torga). Recuperado de http://s3.amazonaws. com/academia.edu.documents/41043660/Tese_ Carlos_Cardoso_final.pdf?AWSAccessKeyId=A KIAIWOWYYGZ2Y53UL3A\&Expires=1498844214\&Signature $=$ Sgdd5eWiD9 $\mathrm{cnQm} \% 2$ F2I20W
06Jp3LE \%3D\&response-content-disposition=in line $\% 3 \mathrm{~B} \% 20$ filename $\% 3$ DOs_Estilos_Educativos_Parentais_e_a_Hipe.pdf

Cerveira, C. M. (2015). Funcionamento das familias: percepção de funcionamento familiar nas diferentes configurações familiares (Dissertação de Mestrado, Instituto Superior Miguel Torga). Recuperado de http:// repositorio.ismt.pt/handle/123456789/486

Cia, F., \& Barham, E. J. (2009). O envolvimento paterno e o desenvolvimento social de crianças iniciando as atividades escolares. Psicologia em Estudo, 14(1), 6774. doi: 10.1590/S1413-73722009000100009

Conboy, J. E. (2003). Algumas medidas típicas univariadas da magnitude do efeito. Análise Psicológica, 2(XXI), 145-158. Recuperado de http://www.scielo.mec.pt/pdf/aps/v21n2/v21n2a02.pdf

Crestani, A. H., Mattana, F., Moraes, A. B., \& Souza, A. P. R. (2013). Fatores socioeconômicos, obstetrícios, demográficos e psicossociais como risco ao desenvolvimento infantil. Revista CEFAC, 15(4), 837-846. doi: 10.1590/S1516-18462013000400013

Cunico, S. D., \& Arpini, D. M. (2014). Conjugalidade e parentalidade na perspectiva de mulheres chefes de família. Psicologia em Estudo, 19(4), 693-703. doi: 10.1590/1413-73722418811

Faria, A. M. (2015). Efeitos da estrutura familiar, parentalidade e coparentalidade no ajustamento psicológico em crianças em idade pré-escolar (Dissertação de Mestrado, Universidade Lusófona do Porto). Recuperado de http://hdl.handle.net/10437/7172

Fleitlich, B. W., Cortázar, P. G., \& Goodman, R. (2000). Questionário de Capacidades e Dificuldades (SDQ). Infanto - Revista de Neuropsiquiatria da Infância e da Adolescência, 1(8), 44-50. Recuperado de http://bases.bireme.br/cgi-bin/wxislind.exe/iah/ online $/$ ? IsisScript $=$ iah $/$ iah. $x i s \& s r c=$ google\&base $=$ LILACS\&lang $=$ p\&nextAction $=\operatorname{lnk} \&$ exprSearch $=275954 \&$ indexSearch $=$ ID

Gomes,L. B., Crepaldi, M. A., \& Bigras, M. (2013). O engajamento paterno como fator de regulação da agressividade em pré-escolares. Paidéia, 23(54), 21 29. doi: 10.1590/1982-43272354201304

Gomide, P. I. C. (2006). Inventário de Estilos Parentais: modelo teórico - manual de aplicação, apuração e interpretação. Petrópolis: Vozes. 
Gomide, P. I. C. (2007). Pais presentes, pais ausentes: regras e limites. Petrópolis: Vozes.

Goodman, R. (1997). The Strengths and Dificulties Questionnaire: a research note. Journal of Child Psychology and Psychiatry, 38(5), 581-586. doi: 10.1111/j.1469-7610.1997.tb01545.x

Leme, V. B. R., Del Prette, Z. A. P., \& Coimbra, S. (2013). Práticas educativas parentais e habilidades sociais de adolescentes de diferentes configurações familiares. Psico, 44(4), 560-570. Recuperado de http://revistaseletronicas.pucrs.br/ojs/index. $\mathrm{php} /$ revistapsico/article/view/12559/0

Leme, V. B. R., \& Marturano, E. M. (2014). Preditores de comportamento e competência acadêmica de crianças de famílias nucleares, monoparentais e recasadas. Psicologia: Reflexão e Crítica, 27(1), 153-162. doi: 10.1590/S0102-79722014000100017

Macana, E. C., \& Comim, F. (2015). O papel das práticas e estilos parentais no desenvolvimento da primeira infância. In G. A. Pluciennik, M. C. Lazzari, \& M. F. Chicaro (Orgs.), Fundamentos da família como promotora do desenvolvimento infantil: parentalidade em foco (pp. 34-46). Recuperado de http:/ /agendaprimeirainfancia.org.br/arquivos/ Fundamentos_Familia.pdf

Marcarini, S. M., Martins, G. D. F., Minetto, M. F. J., \& Vieira, M. L. (2010). Práticas parentais: uma revisão da literatura brasileira. Arquivos Brasileiros de Psicologia, 62(1), 119-134. Recuperado de http:// pepsic.bvsalud.org/scielo.php?script=sci_arttext\& pid $=$ S1809-52672010000100013

Manfroi, E. C., Macarini, S. M., \& Vieira, M. L. (2011). Comportamento parental e o papel do pai no desenvolvimento infantil. Revista Brasileira Crescimento e Desenvolvimento Humano, 21(1), 59-69. Recuperado de http://pepsic.bvsalud.org/scielo.php?script $=$ sci_arttext\&pid =S0104-2822011000100007

Marin, A. H., Piccinini, C. A., \& Tudge, J. R. H. (2011). Estabilidade e mudança nas práticas educativas maternas e paternas ao longo dos anos pré-escolares da criança. Psicologia: Reflexão e Crítica, 24(1), 71-79. doi: 10.1590/S0102-79722011000100009

Marin, A. H., Piccinini, C. A., Gonçalves, T. R., \& Tudge, J. R. H. (2012). Práticas educativas parentais, problemas de comportamento e competência social de crianças em idade pré-escolar. Estudos de Psicologia de Natal, 17(1), 05-13. doi: 10.1590/ S1413-294X2012000100002

Marôco, J. (2014). Análise estatística com o SPSS (6 ed.). Pero Pinheiro, Portugal: Ed. Reportnumber.

Mondin, E. M. C. (2006). Contexto e comportamento: definindo as interaçôes na familia e na pré-escola (Tese de Doutorado, Universidade Estadual Paulista). Recuperado de https://repositorio.unesp.br/ handle/11449/102237

Muniz, M., Gomes, C. M. A., \& Pasian, S. R. (2016). Factor structure of Ravens's Coloured Progressive Matrices. Psico-USF, 21(2), 259-272. doi: 10.1590/1413-82712016210204

Nunes, S. A. N., Faraco, A. M. X., Vieira, M. L., \& Rubin, K. H. (2013). Externalizing and internalizing problems: contributions of attachment and parental pratices. Psicologia: Reflexão e Crítica, 26(3), 617-625. doi: 10.1590/S0102-79722013000300022

Pasquali, L. (2003). Psicometria: teoria dos testes na psicologia e na educação. Petrópolis: Vozes.

Patias, N. D., Siqueira, A. C., \& Dias, A. C. G. (2012). Bater não educa ninguém! Práticas educativas parentais coercitivas e suas repercussões no contexto escolar. Educação e Pesquisa, 38(04), 981-996. doi: 10.1590/S1517-97022012000400013

Patias, N. D., Siqueira, A. C., \& Dias, A. C. G. (2013). Práticas educativas e intervenções com pais: a educação como proteção ao desenvolvimento dos filhos. Mudanças - Psicologia da Saúde, 21(1), 29-40. doi: 10.15603/2176-1019/mud.v21n1p29-40

Pinheiro, M. A. F. M. (2015). Parentalidade, adaptação e temperamento da crianç: estudo com uma amostra clínica de crianças em idade escolar (Dissertação de Mestrado, Universidade de Lisboa). Recuperado de http:// hdl.handle.net/10451/23067

Sakuramoto, S. M., Squassoni, C. E., \& Matsukura, T. S. (2014). Apoio social, estilo parental e a saúde mental de crianças e adolescentes. O mundo da saúde, 38(2), 169-178. Recuperado de http://bvsms. saude.gov.br/bvs/artigos/mundo_saude/apoio_ social_estilo_parental_mental.pdf

Salvador, NA. P. V., \& Weber, L. N. D. (2005). Práticas educativas parentais: um estudo comparativo da interação familiar de dois adolescentes distintos. Interação em Psicologia, 9(2), 341-353. doi: 10.5380/ psi.v9i2.4782 
Salvo, C. G., Silvares, E. F. M., \& Toni, P. M. (2005). Práticas educativas como forma de predição de problemas de comportamento e competência social. Estudos de Psicologia de Campinas, 22(2), 187-195. Recuperado de http://bases.bireme.br/cgi-bin/ wxislind.exe/iah/online/?IsisScript $=\mathrm{i} a \mathrm{ah} / \mathrm{i} a \mathrm{~h}$.xis\& src $=$ google $\&$ base $=$ LILACS\&lang $=$ p\&nextAction $=\operatorname{lnk} \&$ exprSearch $=423904 \&$ indexSearch $=$ ID

Santos, Q. S. G. (2015). O envolvimento paterno em famílias de diferentes niveis socioeconômicos (Dissertação de Mestrado, Universidade Federal da Bahia). Recuperado de http://repositorio.ufba.br/ri/handle/ri/19159

Venâncio, A.B. (2015). Envolvimento paterno, coparentalidade e equilíbrio trabalho-familia: um estudo correlacional (Dissertação de Mestrado, Universidade de Lisboa). Recuperado de http://hdl.handle. net $/ 10451 / 23012$

Vieira, M. L., Bossardi, C. N., Gomes, L. B., Bolze, S. D. A., Crepaldi, M. A., \& Piccinini, C. A. (2014). Paternidade no Brasil: revisão sistemática de artigos empíricos. Arquivos Brasileiros de Psicologia, 66(2), 36-52. Recuperado de http://www.redalyc.org/ html/2290/229031583004/

Wielewicki, A. (2011). Problema de comportamento infantil: importância e limitações de estudos de caracterização em clínicas escolas brasileiras. Temas em Psicologia, 19(2), 379-389. Recuperado de http://pepsic.bvsalud.org/scielo.php?script=sci_ arttext\&pid=S1413-389X2011000200003

Woerner, W., Fleitlich-Bilyk, B., Martinussen, R., Fletcher, J., Cucchiaro, G., Dalgalarrondo, P., ... Tannock, R. (2004). The Strengths and Difficulties Questionnaire overseas: evaluations e applications of the SDQ beyond Europe. European Child \& Adolescent Psychiatry, 13(Suppl. 2), II47-II54. doi: 10.1007/s00787-004-2008-0

Recebido em: 17/08/2017

Reformulado em: 18/01/2019

Aceito: 20/02/2019 
About the authors:

Aline Sanches Politi Sebastião holds a Masters from the Faculty of Philosophy, Sciences and Languages of the Universidade de São Paulo (FFCLRP-USP) and is a clinical psychologist.

ORCID: https://orcid.org/0000-0001-8981-1026

E-mail: atendimento@alinepoliti.com.br

Ana Paula Casagrande Silva Rodrigues is a PhD student at the Graduate Program in Mental Health of the Ribeirão Preto Medical School of the Universidade de São Paulo (FMRP-USP), holds a Masters from FMRP-USP and works as a psychologist at the Hospital das Clínicas of FMRP-USP.

ORCID: https://orcid.org/0000-0001-9672-5118

E-mail: anapaulacasagrande@usp.br

Fernanda Aguiar Pizeta is a post-doctoral fellow at the Department of Psychology of the Faculty of Philosophy, Sciences and Languages of the Universidade de São Paulo (FFCLRP-USP). She holds a Masters and a PhD in Sciences from USP and is a professor at the Department of Psychology of the Universidade de São Paulo, as well as a Judicial Psychologist at the Court of Justice of the State of São Paulo in Ribeirão Preto-SP.

ORCID: https://orcid.org/0000-0002-9864-1054

E-mail:fepizeta@gmail.com

Sonia Regina Loureiro is a psychologist, Master, and $\mathrm{PhD}$ in Sciences from Universidade de São Paulo, lecturer at the Ribeirão Preto Medical School-USP, advisor professor at the Graduate Programs in Psychology at FFCLRP-USP and at the Graduate Program in Mental Health of the Ribeirão Preto Medical School-USP. Develops research activities with instruments and evaluation procedures in different psychosocial contexts.

ORCID: https://orcid.org/0000-0001-9423-2897

E-mail: srlourei@fmrp.usp.br

\section{Contact:}

Av. 15 de Novembro, 418, Centro

Jaboticabal-SP, Brasil

CEP: $14870-600$

Contact number: (16) 3202.4733 / (16) 99604.4043 